\title{
The tyranny of immaterialism: Refusing the body in The Winter's Tale
}

\author{
Camilla Caporicci \\ Ludwig Maximilian University, Germany
}

\begin{abstract}
The aim of this study is to analyse the way Shakespeare's work reveals the failure - in both private and public lives - of a system of thought in which the body is construed as a mere receptacle of immaterial and "superior" entities, supposedly governed by rational kinds of political and social power. After a brief consideration of Measure for Measure as a play focused on the political danger of denying the material aspect of the individual, The Winter's Tale will be seen as presenting a similar problem. Here, the aspiration to an ideal of absolute purity and the consequent demonization of the sexualized flesh, deriving from both Puritan theology and neo-Platonic philosophy, merges with the anxiety towards the "rebellious" body fostered by sixteenth century medical science, constituting the disruptive force that initiates the plot. This attitude of denial of the body, linked to political power, leads to both a psychological breakdown and, in the public sphere, to a regime of tyranny.

KEYWORDS: Shakespeare; Renaissance philosophy; Renaissance medical science; Puritanism; Body; Sexuality; Machiavelli; Tyranny; Measure for Measure; The Winter's Tale.
\end{abstract}

\section{Introduction}

The study of human nature, the definition of man's ontological essence, is a particularly relevant issue in Shakespeare's work, 


\section{Caporicci}

associating him with one of the main concerns of an entire age* Shakespeare writes in a period in which the nature of man was the centre of a very complex and animated debate, to which a variety of thinkers - from philosophers to poets, from politicians to theologians and physicians - contributed. The concept of man emerging from this heterogeneous twine of different perspectives was consequently multifaceted. Nonetheless, a specific principle can be said to have constituted the basis of the Renaissance anthropological paradigm: the principle of hierarchical dichotomy. As Jonathan Sawday writes, the categories according to which human nature was conceived, bounded by theology and cosmology, did not allow the human body to be thought of as a discrete and self-significant entity. A belief in the presence of a superior essence - a soul or a thinking entity informed all possible perspectives of the body, whose primary function was to act as a vessel of containment for the more significant feature of the soul (Sawday 1995:16). This perpetual dualistic struggle between body and soul represents the ontological axiom upon which the concept of man was built; an axiom that found its raison d'etre both in the philosophical and the theological paradigms of the period.

From a purely philosophical standpoint, the current of thought that constitutes the basis of the Renaissance anthropological paradigm is a deeply Christianized combination of Stoicism and neoPlatonism. These philosophical currents present an essentially dualistic concept of man, divided into a vile and a noble part. Stoicism preaches an ideal of virtue founded on the absolute control of passions and bodily desires, judged as destructive and essentially evil elements. On the other hand, neo-Platonism, much more optimistic about man's possibilities of perfection, considers human beings to be wonderful creatures, "great miracles,"1 but only insofar as they choose to transcend their most corporeal selves and follow their pure intellect to become angelic minds. Reaffirming a conflict that can be traced back to Plato's Phaedrus - where the soul is described as striving to achieve dissociation from its bodily existence

\footnotetext{
* I would like to thank the two anonymous referees for the generosity and intelligence of their revisions. I feel that, by following their valuable suggestions, I have produced a much better article than the one I originally submitted.

${ }^{1}$ This definition of man, attributed to Hermes Trismegistus, is expressed by Pico della Mirandola at the beginning of his Oratio De Hominis Dignitate (2004:103).
} 
- the neo-Platonic body does not participate in the realization of the most authentic nature of man because, as Giovanni Betussi asserts, "l'anima è l'uomo, ed in quella consiste la vera bellezza. Ed il corpo è la sua prigione ed il suo sepolcro" ["Because man is his soul, and in that consists true beauty. And the body is his prison and his sepulchre"] (1968:20; my translation). The soul, as Ficino writes, needs to detach itself from the physical body and adhere to the divine, and only in doing so will it truly become copula mundi (1962:I.151).

Both Stoicism and neo-Platonism, promoting an ascetic and "mind-centred" ideal of man, had a strong influence on Renaissance England. Stoic thought reached the country through many different sources - from Boethius' Consolationes (in Chaucer's and Queen Elizabeth's translations) to the Stoic ideas Christianized by Paul, Augustine, and Aquinas; from Stoic authors ${ }^{2}$ to the repository of quotations filtered by Dante, Petrarch, Boccaccio, Erasmus, Guevara and Montaigne; and finally Justus Lipsius on constancy in John Stradling's sixteenth-century translation (López-Peláez Casellas 2004:98). As López-Peláez Casellas writes, ${ }^{3}$ Stoicism was one of the most powerful philosophical constructs of the Renaissance period (2004:93). As for neo-Platonism, in the 1570s, after Colet's cosmogonist Plato and Thomas More's political one, neo-Platonic theories of love and beauty - the Plato of the Symposium - arrived in England, mainly through the works of the French neo-Platonists and the treatises by Bembo, Pico della Mirandola, Annibale Romei and Baldassarre Castiglione (especially in Hoby's famous 1561 translation of The Courtier). These works were widely read among English intellectuals, in both their original and translated versions. Moreover, minor neo-Platonic authors such as Diaccetto and Della Barba, whose works appear in the libraries of the period as much as those by Ficino, were also known to English thinkers. The neoPlatonic idea of man as a "great miracle," whose soul strives to escape the terrestrial physicality of the body, easily merged with the purely Christian ideal, and spread through England, strongly influencing the thought and literature of the period.

\footnotetext{
${ }^{2}$ Mainly Virgil, Horace, Cicero, Seneca, Plutarch, and Marcus Aurelius.

${ }^{3}$ Another scholar whose work has particularly contributed to the understanding of the relations between Stoicism and English Renaissance literature is Ben Schneider (1993; 1995).
} 


\section{Caporicci}

From a strictly religious standpoint, the limits of the optimistic neo-Platonic concept of man are found in Christian, and specifically Protestant, anthropological pessimism. As Alistair Fox writes: "At the heart of Elizabethan Protestantism lay a deepened sense of human sinfulness [...] [which] sprang from the Calvinist conviction that human nature was inherently depraved" (1997:61). Inherited from St. Augustine and patristic writers, this pessimistic and dichotomous idea of man individuates the dark mark of original sin in the human body, particularly in its sexual connotations. For this reason, this sin can only be redeemed through the annihilation of the body and its desires. As Luther writes, the body contains the seeds of the Devil and is, therefore, inevitably inclined towards evil. For this reason, God hates the "sinful body" and commands men to hate, mortify, and destroy it (1976). Concurrently, Calvinistic theology, with its obsessive desire to chart the inner state of each individual's spiritual well-being, promoted an even more ferocious battle between the body - perceived in its disobedient longing for sensual existence - and the soul. Amongst Puritans, the inner anxiety of Calvinist doctrine became institutionalized, producing a fanatical refusal of the body and its desires. The ascetic tension present in medieval English spirituality found a point of convergence in the Protestant rejection of the flesh, reinforcing the dichotomous concept of man proper to Christian ontological anthropology and fostering a body-denying attitude in both theory and practice.

Paradoxically, the optimistic neo-Platonic anthropology which considers the human being to be capable of reaching absolute purity and perfection, and the pessimistic demonization of man's material aspects, resulting in the generalized idea of the sinfulness inherent in the human race, share a common ontological matrix. This matrix is based on the rejection of the body, which is perceived as the negative pole of a hierarchically oriented dichotomy according to which human nature as well as the universe are organized. Mastery over the body and its desires, the endless war against the sin inherent in the flesh, asserts itself as a key feature in Renaissance culture, and provides the framework in which the period's anthropological paradigm is to be understood (Sawday 1995:20).

Although Stoicism and neo-Platonism are the cornerstones of the anthropological paradigm predominant in the Renaissance, it would be a mistake not to acknowledge the existence of other conflicting 
currents of thought circulating in Europe in this period. As Richard Stier recently highlighted, the idea of a "homogeneous" Renaissance, uniform in the triumph of a single worldview, is at odds with the inconsistencies generated by divergent voices (2011). Shakespeare is one of those voices. The investigation of Shakespeare's work from a body-centred perspective is not new in the field of Shakespearean criticism. As Keir Elam noted as early as 1996, in the three preceding decades Shakespeare studies witnessed a "corporeal turn," "a shift from a primary concern with 'language' to a primary concern with the body" (1996:142-43). To paraphrase Elam, the body had been counted as single-sexed, double-natured, tremulous (Barker 1984), enclosed (Stallybrass 1986), carnivalized, effeminized, intestinal, consumed, embarrassed (Paster 1993), sodomized, disease-ridden, and emblazoned (Sawday 1995). Since Elam's work, the body has been further considered as interiorized (Hillman 2007; Schoenfeldt 1999), gendered (Rutter 2001), fragmented (Owens 2005), temporal (Siemon 2001) and indeterminate (Sanders 2006). At the same time, the early modern use of the body as a political metaphor has also been thoroughly investigated. Following Kantorowicz's famous study on the king's two bodies (1957), the concept of the "body politic" - "the most frequently used metaphor for the state in early modern political discourse" (Hadfield 2004:131) - has been widely analysed within the context of Shakespeare's work. As Dustin Gish and Bernard J. Dobski write, "there may be no greater account or anatomy of the Body Politic in English language than what one discovers in Shakespeare's plays and poetry" (2013:1).

The study of the "body politic" as a metaphor intertwines with the attention recently paid to the body's materiality. However, the two different discourses have tended to remain relatively separate. While the Shakespearean body was examined and dissected through a variety of different approaches, those works investigating Shakespeare's output from a political standpoint usually continued to treat the "body" mainly as a metaphor. The result of this tendency is that the deep interaction between political, philosophical, and anthropological paradigms as it appears in Shakespeare's work is still open to investigation. In particular, Shakespeare's representation of the political effects of a particular concept of the body appears to me as extremely interesting, as it shows the risks the poet considers inherent in the most ascetic and dichotomous elements of the Renaissance idea of man. 


\section{Caporicci}

The aim of this study is to analyze the way Shakespeare's work reveals the failure - in both private and public life - of a system of thought in which the body is construed as a mere receptacle of immaterial and "superior" entities, supposedly governed by rational kinds of political and social power. In particular, the inconsistency of this concept of man will emerge in the analysis of a play not often examined in terms of its political and anthropological implications: The Winter's Tale. After a brief consideration of Measure for Measure as a play directly focused on the political danger of denying the natural and material aspect of the individual, The Winter's Tale will be seen as presenting a similar - though perhaps more complex - problem. As in Measure for Measure, the attitude of denial of the body, linked to political power, leads to both a psychological breakdown and to a regime of tyranny in the public sphere. Moreover, in Act V, Shakespeare interlaces the political and anthropological discourses with a particular concept of art also stemming from the great Christian and neo-Platonic Renaissance code, thus calling into question the dominant paradigm in its many different, coherent faces.

\section{Measure for Measure}

A Shakespearean scholar aiming to analyse the way in which a particular attitude toward the human body affects both personal and public life can easily find Measure for Measure to be an interesting, yet obvious, starting point. In this play, the risk stemming from a political power unable to confront properly the bodily aspects of its subjects is made extremely clear.

As the Duke's first words seem to suggest, one of the main themes of the play is "Of government the properties to unfold" (1.1.3). In facing this difficult task, Shakespeare joins the long list of Renaissance writers dealing with the ideal form of government, and the ideal prince. Critics have often referred to the political treatises of the period, primarily Machiavelli's, in order to "situate" the form of government Shakespeare may be proposing. Norman N. Holland, for instance, emphasises the link between the Duke of Vienna's actions and those of Cesare Borgia, as described in Machiavelli's Il Principe, concluding that: "Shakespeare's Duke is on Machiavelli's side" (1959:20). 
To describe the nature of the Duke's policy as more or less Machiavellian is not the aim of this study. However, as the treatment of the human body is the central subject here, one aspect of Machiavelli's political philosophy - which was undoubtedly in some form present in Shakespeare's mind while writing Measure for Measure - may be relevant for understanding the anthropological basis of the play. This aspect is what Roberto Esposito calls Machiavelli's "relationship with the vital, corporeal and animalistic layer, which is at the base of human actions" (2010:25; my translation). Power, for Machiavelli, is not above and separated from the natural and "original" aspects of human life, but instead is deeply rooted in an instinctive, corporeal, and, in some way, animalistic world. Machiavelli's intention of dealing with the "verità effettuale della cosa" ["effective truth of the matter"] (1976:60; my translation) is in this sense also an expression of his frustration with humanistic anthropology, according to which "the beast" (which can also be interpreted as "the body") is considered the lowest level to which men return when falling from their divine state, or a primitive and temporary condition to be definitively surpassed by political order. The fundamental starting point of Machiavelli's theory is the full acceptance of the complex and dynamic nature of the human being, and not only in terms of a negativity inherent in the subjects (the "body" of the state), which needs to be controlled and repressed by the political power (the "head" of the state), as in Hobbes, but also as a natural state and a source of strength and power for the subjects as well as the prince. This situation is expressed well by the images of the prince as a centauro (centaur) and the union of volpe and leone (fox and lion).

The rejection of this humanistic anthropology, in favour of the concept that the human being is a complex and non-hierarchic unity of mind and body, appears also to be one of the bases of Shakespeare's works. When a character refuses to acknowledge his "dark," instinctive, and corporeal side, by presenting himself as a purely spiritual and rational being whose body is a mere vessel of immaterial and noble elements, he often ends up either changing his worldview, or being damaged by it.

The problem is much more serious when the character concerned is a man wielding political power, for in this case not only is his own health in danger, but so too is the safety of the entire State. An 


\section{Caporicci}

illustrative example of this can be found in Measure for Measure. The problem that many critics have indicated as the central issue of the play, the balance between law and mercy - a problem also crucial in The Merchant of Venice -, is not accidentally connected with that of body-denial, as it arises in connection with those frailties most deeply rooted in the material nature of men, related to their physical needs and pleasures, most notably sexual appetite.

Shakespeare quite explicitly condemns the excessive rigour with which Lord Angelo intends to punish premarital sexual intercourse by making this character villainous. The underlying cause of Angelo's misrule, on a personal and political level, is also wellestablished in the text. He is a precise, "a word that was used to stigmatise a theological or ecclesiological position and one often applied to Puritans" (Hamilton 1992:111-12); "A man of stricture and firm abstinence" (1.3.12), "who never feels |The wanton stings and motions of the sense, |But doth rebate and blunt his natural edge | With profits of the mind, study, and fast" (1.4.57-60). Angelo's obstinate refusal of his natural and material aspects, especially his sexuality, makes him not only unable properly to balance law and mercy in his administration of justice, but also brings him to a morbid and unhealthy confrontation with the other sex, one which ultimately leads him to a political as well as personal failure.

On an individual level, the fanaticism with which Angelo refuses to accept his bodily nature as a legitimate part of himself prevents him from dealing with his sexual impulses in a natural way. As a result, he becomes morbidly obsessed with Isabella. Perceiving desire as sinful and shameful in itself, he already feels damned once he has experienced it, and is therefore unable to prevent his descent into crime - "I have begun, |And now I give my sensual race the rein" (2.4.159-60). On the other hand, the deputy's attitude towards his own body does not lead him to a better political outcome. Given the essential ontological sameness of those who rule and those who are ruled as discussed above, Angelo's inability to recognize and accept his own nature in its completeness prevents him from understanding his subjects, and consequently from governing them properly. Not only Lucio, whose authority is questionable, but even Escalus implicitly indicates the cause of Angelo's political errors as the rejection of his own flesh. Contextually, the Duke's main purpose seems to be, from the outset, not enforcing the law - his final 
resolutions being the very denial of this purpose -, but rather to expose the inconsistency and dangerous character of Angelo's attitude towards men's bodily nature.

This body-denying attitude leads Angelo to complete political failure, which causes unanimous discontent among both the lower and the upper classes. Feeling sinful in his own body, Angelo needs first to deny it through psychological self-castration and then through the censure of his subjects' bodies, with an obsessive severity springing from his loss of self-control. He thus becomes a "tyrant." This epithet, central to the Renaissance treatises on the ideal prince, is more or less overtly attributed to the deputy by Isabella, ${ }^{4}$ by the Duke himself, ${ }^{5}$ and by Claudio, who meaningfully links Angelo's "tyranny" (1.2.151) to the image of the governor riding and restraining with spurs a restless horse: the "body public" (1.2.147). While subtly reminding us of the Platonic chariot allegory, in which the lustful body is represented as an unruly horse, this representation of the relationship between the governor and the "public body" clearly refers to the images, often found in the treatises of the period, of the state as composed of a body - the totality of the subjects - and a head - the king. However, the Shakespearean image goes beyond the traditional figure by entirely separating the body (animal) - which is represented as a disconnected, not human because not rational, entity - from the head of the state (human). This separation, reflecting Angelo's refusal to admit any similarity of the flesh between himself and his subjects, transforms the metaphor of rightful government into one of tyranny. It thus reveals the inadequacy, on both the psychological and political levels, of a system of thought in which the natural, ontological matrix proper to all mankind is denied in favour of a purely rational and spiritual ideal.

\section{The Winter's Tale}

Measure for Measure is perhaps the play in which the dangers of denying the body, especially when linked to power, are most

\footnotetext{
4 " $\mathrm{O}$, it is excellent | To have a giant's strength, but it is tyrannous | To use it like a giant" (1.2.109-11).

5 "Were he mealed with that | Which he corrects, then were he tyrannous" (4.2.84-85).
} 


\section{Caporicci}

explicitly asserted. This same statement, though in a more covert and complex way, can be found in another play addressing the relationship between personal behaviour and political power: The Winter's Tale. In this play, the disruptive force that initiates the plot is generated when the aspiration to an ideal of absolute purity and the consequent demonization of the natural and sexualized flesh, deriving from both Puritan theology and neo-Platonic philosophy, merges with anxiety about the "rebellious" body-interior fostered by sixteenth-century medical science. The psychological and political consequences of this complex intertwining of body-denying impulses are displayed in a most subtle way, shown rather than explicitly asserted, until the final scene, where the image of the statue turning into flesh marks the reconciliation between the king's mind and the body of both his wife and his state.

One of the main issues that have puzzled critics working on the The Winter's Tale is the actual cause of Leontes' sudden and apparently unwarranted jealousy. Some critics have stressed the latent homosexual desire between the two kings, Leontes and Polixenes (Johnson 1998:187-217), while others have read Leontes' unreasonable treatment of his wife as the result of the king's anxiety towards female power. This is, for instance, the interpretation of Lynn Enterline, who, underlining Hermione's success in convincing Polixenes to stay (when Leontes could not), links the king's outburst of jealousy to an anxiety provoked by the power of his wife's speech (2000:198-226). According to Enterline, this event engenders a rhetorical rivalry between male and female speech that turns into a sexual anxiety when the king minimizes his wife's superior rhetorical skills by interpreting them narrowly as the consequence of her erotic power. Both of these interpretations are of use in understanding this most difficult play. However, by analysing more deeply the king's attitude towards his wife's body, it is possible to shed further light on Leontes' strange obsession, discovering again in the refusal of the very materiality of the human, and particularly feminine, body, one of the main causes of the king's personal and political mistakes.

Crucial to this analysis is Polixenes' initial description of the two kings' infancy. His description reflects the idealistic and Edenic dream that Leontes, and probably Polixenes also, have projected onto their own past, and still perceive as a highly desirable state. 
This Eden, in which Christian, neo-Platonic and Arcadian characteristics intertwine, significantly presents the two boys as "twinned lambs" (1.2.69) who exchange "innocence for innocence" (1.2.71) and, not knowing "the doctrine of ill-doing" (1.2.72), can answer heaven "not guilty" (1.2.76). Whether this is a veiled homosexual fantasy or not, it is clear that no sexual appetite enters this golden time until the appearance of female bodies (those of the two queens). As in the biblical story of Adam and Eve, these bodies violently insert themselves into the once eternally static paradise "Two lads that thought there was no more behind | But such a day tomorrow as today, |And to be boy eternal" (1.2.64-66) -, bringing with them time, blood, and temptations: the sinfulness of matter and flesh. Failing to perceive the actual danger and the truth hidden in her own words, Hermione meaningfully jokes: "Of this make no conclusion, lest you say | Your queen and I are devils [...] If you first sinned with us" (1.2.83-86). This initial dialogue provides us with an understanding of Leontes' obsession, linking the fall from the Heaven of absolute purity to the queen's body, which is perceived as the first sin. Such a reading of reality is clearly influenced by a Christian, and particularly Augustinian, vision of the world, where an Edenic nature is opposed to the post-lapsarian nature of matter and the flesh.

The memory of this state of innocence and the cause of his "fall" from it lead Leontes to a sudden demonization of his wife's sinful body, especially when she re-enacts towards his past companion in innocence the same seductive movement with which she entered the king's life. The image of soft hands sealing a bond of love - "I could make thee open thy white hand | And clap thyself my love" (1.2.105106) - is now interpreted by Leontes in a most morbid way: his friend and his queen are perceived to be "paddling palms and pinching fingers" (1.2.117), and, worse yet, "mingling bloods" (1.2.111). The fluid, open, and porous nature of Hermione's body consistent with the Galenic and "humoral" vision of the body so crucial in the Renaissance ${ }^{6}$ - repulses Leontes, who starts to become obsessed by it.

${ }^{6}$ The Galenic and "humoral" idea of the body, as described by Paster, is "characterized by corporeal fluidity, openness, and porous boundaries" (1993:8). 


\section{Caporicci}

The perception of Hermione's body as "grotesque" in Bakhtinian terms - a body that "is not separated from the rest of the world. It is not a closed, completed unit; it is unfinished, outgrows itself, transgresses its own limits" (1993:26) - causes Leontes to feel anxious and disgusted, especially towards "those parts of the body that are open to the outside world, that is, the parts through which the world enters the body or emerges from it" (1993:26), the body's thresholds and its sites of pleasure. In this sense, nothing could be more disturbing than the queen's pregnant body, a "grotesque" "plenitude, full of activities apart from mind through which it expresses its unity with and sense of belonging to the natural world." 7 This king, dreaming of an existence disconnected from the obscurity and heaviness of matter, is unable to cope with it.

Deviating from his source, Pandosto, in which the queen's pregnancy is discovered only after she is imprisoned, far from the other characters' and the audience's eyes, Shakespeare's deliberate choice to bring Hermione's pregnant body onto the stage is quite significant. Its presence on stage in all its heavy, bloated roundness, disturbs the "clean" and "neat" Platonic male world the kings speak of ("We must be neat - not neat, but cleanly" [I,ii, 125]), and pollutes the "uncontaminated" dream of Leontes with its overabundance of flesh, of matter. As in Measure for Measure, where Juliet's pregnant body is disturbing to the deputy, who reads in it, written with "character too gross" (1.2.144), all the danger and foulness of the sexualized flesh, in the replenished body of his wife Leontes perceives the triumph of a principle divergent from his pure and "fleshless" ideal. As Maria del Sapio Garbero writes, the queen's body appears to Leontes "as the persuasive principle of a evilness of the matter that bends, bending with itself every other thing. [...] It illustrates in an obvious way what living beings own to Nature, and makes the original stain seem irredeemable. It roots them in a fallen world, which originates in impurity" (2003:29; my translation). The immobility and "linearity" of the Edenic world come into violent collision with this round and mysterious growing belly that hides deep inside its flesh the perpetual movement with which matter reproduces itself, in a vertiginous revolving of tissue and blood.

7 This is the way Paster defines the humoral and grotesque body in his The Body Embarassed. Drama and the Disciplines of Shame in Early Modern England (1993). 
The king's denial of the materiality of his own origin and his disgusted obsession with the visible incarnation of that "unclean" procreation process, leads him to a destructive madness that craves for the annihilation of the ontological and epistemological darkness implicit in the mystery of the growing womb. In accordance with most Renaissance medical literature, this organ is perceived as obscure and able to "infect" and "defile" the whole body, linking pregnancy with disease, and producing "an understanding of the maternal body as polluted and polluting" (Paster 1993:165). The king's language reflects his morbid obsession and becomes more and more obscene towards his queen, deforming her features through bestial imagery - "How she holds up the neb, the bill to him" (1.2.184) -, and expressing in this the neo-Platonic association of sexuality and bestiality. He also focuses his afflicted imagination on the "grotesque" nature of Hermione's body as "open," and continuously in sexual exchange with the "dungy earth" outside of it. The "gates" of the body are "opened" (1.2.198); there is "No barricado for a belly" (1.2.205), it "will let in and out the enemy" (1.2.206). Contextually, the imagery of the "infection" and "disease" continues to spread through the play's words. However, the infection is not only the presumed sexual pollution inseminated in Hermione's body by her lustful desires - "Were my wife's liver |Infected as her life" (1.2.306-307); "Who does infect her?" (1.2.308) etc. It is not only a disease that is felt to be contaminating her blood and her milk (in accordance with the medical thought of the period, which conceived the womb and the breast as strictly connected to one another), as it clearly appears in the king's statement in removing his male child from the mother - "Give me the boy. I am glad you did not nurse him [...] you | Have too much blood in him" (2.1.58-60) -, and in the conscious words of the queen herself: "My second joy, |And first fruits of my body, from his presence |I am barred, like one infectious" (3.2.95-97). The infection is also the consciousness of the blood, the spectre of the flesh that enters Leontes' fantasy of absolute purity "infecting" his brain (1.2.147), exactly as the consciousness of the spider's presence in the cup "infects" his knowledge (2.1.44), causing the violent vomiting of the abhorrent material. In an era in which the anatomical study of the human body's interior was calling into question centuries-old certitudes both ontological as well as epistemological, ${ }^{8}$ Leontes'

\footnotetext{
${ }^{8}$ For a study of the history of anatomy in early modern period, see Sawday (1995).
} 


\section{Caporicci}

almost desperate attempt to keep his mind free from the "visceral knowledge" (as David Hillman terms it) reflects an anxiety experienced by many early modern people. As Hillman affirms, The Winter's Tale represents Shakespeare's most concise portrayal of this denial, repeatedly thematising "the desire not to know, or not to 'dare to know that which I know' (4.4.452) - not to dare, as Nietzsche put it, to believe one's own entrails" (1997:94). This is because, as Sawday writes, the knowledge of the body-interior's abysses "speaks directly of our own mortality" (1995:12), and of our ineradicable connection with the realm of nature and of matter.

Stemming from his obsessive rejection of the sexualized flesh, Leontes' fear and disgust towards the depths of the body effortlessly merges with his jealousy, leading him to perceive, in accordance with a common Renaissance understanding of procreation, the queen's belly as the fruit of her illicit sexual pleasure. Due to the absence of effective contraception, "sex and pregnancy went hand in hand in the Renaissance imagination" (Jardine 1989:130); moreover, the Galenic view of conception produced "a common culture of procreational knowledge in which women's sexual pleasure was seen both by laymen and doctors as necessary for fecundity" (McLaren 1984:21). ${ }^{9}$ As a result, the pregnant woman could be seen as an image of her own fulfilled sexuality, "her belly an eloquent narrative of her illicit desires" (DiGangi 1993:593), and this is the way Leontes seems to perceive Hermione's growing body. Absorbed in this complex and contradictory fusion of Puritan theology and Renaissance science so common in the early modern period, Leontes decides, as does Angelo in Measure for Measure, ${ }^{10}$ to hide this sinful and disturbing body by shutting Hermione in prison, where she can "swell" at her "pleasure": "let her sport herself |With that she's big with, for 'tis Polixenes | Has made thee swell thus" (2.1.62-64). In so doing, Leontes reveals his anxiety towards something that he cannot accept (because accepting it would also mean acknowledging his own origins as embedded in this bloody and fleshy stirring), and that, for the very reason of his denial, he cannot understand nor govern.

\footnotetext{
${ }^{9}$ See also Laqueur (1986:1-16; 1990).

${ }^{10}$ Almost disgusted by Juliet's pregnant body, which looks to him "overfed" with sin, Angelo cannot but hide it from view - "See you the fornicatress be removed" (2.2.23) and imprison it where the abhorrent process of generation can take place out of sight.
} 
In trying to rule over his wife's sexualized body and prove his power in disposing of it at will, Leontes becomes, like Angelo, a "tyrant." He does so on a personal level, obliging the queen to give birth in prison and depriving her of "the child-bed privilege," exposing her newly delivered body to the public gaze before the prescribed time. Even worse, he demonstrates his tyranny by planning her death, possibly by fire (a way to dispose of the body that suggests the most traditional process of purification), and by ordering the death of the infant Perdita (originally to be burned like her mother), perceived to be the rotten fruit of the sinful belly. But he also proves to be a tyrant on the political front. Leontes, who as a male and husband is entitled to be master over his wife's body, feels that as king and "head" of the state he is similarly sanctioned to rule over the body politic. Instinctively associating the queen's disobedient and polluted body with the body politic, he perceives the loss of control over the former as a symptom of a similar risk in the political sphere. Projecting the infection he perceives in his wife's body onto the body politic, the king feels, in his political role, as the head of a diseased, and therefore potentially treacherous, body "many thousand on's | Have the disease" (1.2.207-208).

The ubiquitous imagery of disease and infection that permeates the entire play is in this sense a clear sign of Leontes' distorted perception; a perception consistent with a common Renaissance vision in which, as Sawday writes, "The defeat of sickness and the establishment of political order were two sides of the same coin. A state in rebellion was a body in sickness. The diseased body was an image of rebellion" (1995:36). Leontes' suspicion of Hermione's rebellious body - a body that defies his purely rational knowledge and that therefore he feels is difficult to control - crosses thus the borders of the personal sphere and invades the king's perception of his "body politic," that is, of his subjects. The king's suspicion begins with the women, who are immediately suspected of lying to hide the supposed illegitimacy of his first-born. Next, in a sudden outburst of obsessive mania, it spreads onto all the subjects, imagined by Leontes as deriding him, and plotting against him. Camillo, his "right-hand" man, is also accused of being a liar and traitor because he affirms the queen's innocence, and when he is obliged to leave Sicilia, Leontes' political nightmare reaches its peak. While Hermione shifts from being merely an "adulteress" (private and physical sphere) to a "traitor" to the state (public and political 


\section{Caporicci}

sphere, 2.1.90-91), the treacherous body politic, so connected in Leontes' mind with the polluted body of the queen, is perceived by the king as plotting to eliminate him both as a man and as king: "There is a plot against my life, my crown" (2.1.49). From this moment on, the king, who has already started to be a tyrant towards his wife, becomes one also on a political level, dismissing the function of his wise counsellors and threatening everyone's freedom of thought and speech by punishment of death: "Our prerogative |Calls not your counsels [...] We need no more of your advise" (2.1.165-70); "He who shall speak for her is afar-off guilty, |But that he speaks" (2.1.106-107). And it is clear from Leontes' continuous attempts to avoid the accusation that he is somehow conscious of the dangers of being considered a tyrant: "Let us be cleared |Of being tyrannous since we so openly |Proceed in justice" (3.2.4-6); "Were I a tyrant, |Where were her life?" (2.3.122-23), etc. Nevertheless, he cannot prevent the rise of general discontent, nor avoid the accusations of his queen - "tyranny |Tremble at patience" (3.3.3031); "Tis rigour, and not law" (3.2.113) - and of the Oracle itself, who defines him as "a jealous tyrant" (3.2.133), clearly linking his inner self and personal behaviour with the politically characterized concept of tyranny. However, it is Paulina, the character who appears to direct, and eventually restore, the play's psychological and political balance, who most emphatically makes the word resound over and over through the stage: "his tyrannous passion" (2.3.28); "something savours |Of tyranny" (2.3.119-20); "What studied torments, tyrant, hast for me?" (3.2.174); "Thy tyranny" (3.2.178); "O thou tyrant!" (3.2.206).

As in Measure for Measure, a troubled relationship with the natural, material aspects of creation, especially when associated with political power, leads to a "sickness" infecting both the individual and the collective life - "a master - one who in rebellion with himself, will have |All that are his so too" (1.2.355-57). The image of disease, used by Leontes to define both his queen's and his state's infected bodies, turns against him repeatedly: in Camillo's words, which individuate instead the sickness in the king's "diseased opinion" (1.2.299) and in his political as well as personal behaviour, which affects the lives of his subjects: "There is a sickness |Which puts some of us in distemper" (1.2.384-385). 
But where does this sickness come from? As I have attempted to demonstrate, the deep roots of Leontes' tyranny consist of his inability to acknowledge and accept the existence of an entire realm independent from that of the mind; a powerful realm which works according to its own laws: the realm of the flesh and nature (the post-lapsarian nature, according to Leontes' interpretation). In a period in which religious, and particularly Puritan, doctrines merged with the first rationalistic aspirations of dominion over nature, Leontes' obsessive desire to bring the mysterious and "rebellious" body of his wife under his control reflects an anxiety not uncommon in the late Renaissance. The king's inability to penetrate the mysteries of this natural realm of the flesh accounts for the violence with which he tries to reduce the power of "great creating nature" (4.4.88) - embodied in Hermione's reproductive body under his purely rational political and social rule. It is only when this nature triumphs over him that he is obliged to admit the impossibility of rational control over every aspect of reality. The king's artificial construction collapses, leaves him naked in front of the unpredictable and absolute character of death: the death of his son and heir Mamillius, and, as Leontes believes, of his queen, whose body is now fully out of his control.

Examined in the light of this opposition between the natural world of the flesh and the artificial and ideal realm of the mind, the play's ending appears quite ambiguous. If it is true that, as some critics have pointed out, by presenting herself as a statue, Hermione is "the subject of an evidently successful, self-imposed discipline of shame, and thus a perfect exemplar of the new bodily regimes of early modern selfhood" (Paster 1993:279), it is also true that the final word is again that of nature, not of art. Deviating again from his source, Pandosto, in which there was no "statue scene," in the final act Shakespeare presents Hermione's body as a sculpture. In so doing, he decides to conclude the play by returning not only to the problem of the relationship between art and nature as exposed through the dialogue between Polixenes and Perdita (4.4.79-103), but also to the initial issue: human ambition in seeking absolute rational control over nature, for a power capable of "mending nature," purging it from its most material aspects.

The image of a statue described as the masterpiece of "that rare Italian master Giulio Romano, who, had he himself eternity and 


\section{Caporicci}

could put breath into his work, would beguile Nature of her custom" (5.2.96-98), and who "so near to Hermione hath done Hermione that they say one would speak to her and stand in hope of answer" (5.2.99-101), clearly suggests a specific relationship between the power of nature and man. The concept of art emerging from these lines appears to be consistent with the main Renaissance aesthetic paradigm, stemming from the great Christian and neo-Platonic code. ${ }^{11}$ According to this paradigm, based largely on a neo-Platonic approach to reality, the function of art is to create forms that, in tending towards the ideal, surpass and transcend nature's creations, giving birth to an artificial, perfected second world. This aesthetic ideal clearly intertwines with specific anthropological and philosophical views, both in the play and in the Renaissance system of thought, fostering the idea of an almost god-like human control over inert matter. Nature would thus be surpassed by a poietic power capable of a generational process autonomous of the fleshy and bloody reproduction that disgusted Leontes and many sixteenth-century thinkers alike.

The petrified body of Hermione can be seen as finally embodying the platonic ideal that Leontes sought in the opening scenes: the perfect fruit of that "artificial" process that not only equals nature but, in Polixenes words, "does mend nature" (4.4.96). Precisely for this reason, this body appears as the exact opposite of the "grotesque" pregnant one that the king had revolted against. The first was open, unfinished, fluid, unstable, and continually in contact with the perpetually moving matter that flows in and out of it. In contrast, this "classical body," again in Bakhtinian terms, is finished, closed off, all surface and no interior, perfect in its archetypal immobility: the celebration of form over matter. This statue, which reminds its audience of both a classical and a devotional image, ${ }^{12}$ appears thus to embody the perfect objective counterpart of Leontes' neo-Platonic and Christian initial ideal. In this sense, the statue represents a kind of monitum, a visible and weighty reproach to Leontes' body-denying attitude - "Does not the stone rebuke me |For being more stone than it?" (5.3.37-38). It shows the results of an

\footnotetext{
${ }^{11}$ This aesthetic paradigm, together with its philosophical implications, was being called into question at the end of the sixteenth century.

${ }^{12}$ The way in which the statue is described and the reactions of the play's characters could easily remind the audience of the Christian images of the Virgin.
} 
artificial "perfecting" of nature obtained by abstracting the essence from the biological substrate, the dark and vital fleshiness deeply rooted in the heart of matter and nature.

Leontes is obliged to confront the outcome of his ideas. What he discovers is that, while the natural growth of Hermione's belly produced the wonder that is his newly found daughter Perdita who is meaningfully presented as a "most peerless piece of earth" (5.1.94), and not of art -, the fruit of his own "conception" is a beautiful but dead body, cold and unsatisfactory: a "poor image" (5.3.57) of the living queen, once endowed with "warm life, |As now it coldly stands" $(5 \cdot 3 \cdot 35-36)$. Leontes' final redemption passes thus through the definitive recognition of the superiority of nature over human rational power, a recognition that will lead him to a desire opposite of the "distillative" and "dissolving" one experienced in the first part of the play. Now that the king's wishes have come true, the growing body replenished with life that he desired to dissolve, to block, cool - "Too hot, too hot" (1.2.110) - and dry up, is desired to regain its fleshiness, to move, warm, and fill itself with blood. This longing manifests itself in the obsessive search for signs of life in the statue: he believes that it moves, breathes, that "The fixture of her eye has motion in't" (5.3.67), "those veins |Did verily bear blood" (5.3.64-65), and that "The very life seems warm upon her lips" $(5 \cdot 3 \cdot 66)$.

The fluid, warm, and mobile elements of the body are thus invoked by the penitent king in the final scene, when he finally recognizes them as inseparable from life itself. This recognition does not remain unrewarded. The stone melts into flesh, reminding the audience of Ovid's famous story of Pygmalion. However, while Ovid's myth spoke of Pygmalion's disgust for female sexual behavior, and his desire to create a statue more beautiful than any natural woman ("qua femina nasci | nulla potest" [Ovid 1995:X.24849]) to eradicate the faults that nature has given her ("vitiis, quae plurima menti |feminae natura dedit" [X.244-45]) - a desire quite similar to Leontes' initial one - the end of The Winter's Tale overturns this assertion. This ambition is not only revealed to be "sick" and dangerous, but also essentially wrong. In Leontes' reaction to the statue of Hermione, and in the ambiguity implicit in this very statue, which is eventually discovered to be the work of nature and not of 


\section{Caporicci}

art, man's aspiration for absolute control over the natural body finds its most definitive limits.

Abandoning her Marian posture, the queen moves, descends from her pedestal, and her husband touches her. Not accidentally, the king's redemption passes through the less spiritual and neoPlatonic of the senses: touch. He touches her body and feels its warmth - "O, she's warm!" (5.3.109) -, the warmth of the flesh, and welcomes it. Those gestures that, at the beginning of the play, had shifted from signs of love to signs of sin and betrayal in Leontes' sick imagination, are again converted into something precious and holy. The body accused of "hanging about Polixenes' neck"13 and consequently tortured for it, can now freely "hang about the king's neck,"14 in an embrace that visually as well as symbolically represents the final pacification between Leontes' mind and the queen's body. This final reconciliation also marks the end of his tyranny: eventually abandoning his despotic ambition over Hermione's body, the king affirms that he will be content with whatever she does and says. ${ }^{15}$

Through this final redemption, Leontes eventually admits the supremacy of nature over any artificially constructed ideal of absolute spiritual purity, and acknowledges the material and corporeal aspects of existence as not only necessary, but also powerful and desirable. It is only at this point that the king's as well as the State's balance can be recovered, and, as Leontes prayed, the blessed gods can finally "Purge all infection" (5.1.168) from everyone's life.

\section{Conclusion}

Writing in a period in which the nature of man, and particularly of man's body in relation to his soul, was the centre of a very animated debate, Shakespeare, with his particular sensibility in the representation of the human, demonstrates a special awareness of the prevailing anthropological paradigms of his time. In particular,

\footnotetext{
13 "he that wears her like her medal, hanging | About his neck" (1.2.309-10).

${ }^{14}$ "She hangs about his neck" (5.3.113).

15 "What you can make her do | I am content to look on; what to speak, |I am content to hear" (5.3.91-93).
} 
his attention to the specific reading of the human body inherent in the most ascetic and soul-centred strands of the Renaissance system of thought - a reading that finds its roots in the theological and philosophical universe of the time along with the development of medical science in the sixteenth century - appears crucial in many of his plays. Particularly interested in the relationship between the inner self and political power, Shakespeare's reflection on the risks implicit in a body-denying approach to reality, both in the private and public spheres, informs some of his most famous works, most notably Measure for Measure, where the nature of the problem is treated in an almost paradigmatic way. However, the investigation of the subtle connection that Shakespeare establishes between the treatment of the natural body and of the "body politic" appears to be an interesting key with which one can interpret not only those plays in which the problem is more explicitly displayed. My reading of The Winter's Tale, a play that has not often been studied in the light of such a connection between anthropological and political discourses, highlights the deep correlation Shakespeare establishes between a certain attitude towards human nature and specific political risks. A reading of this kind opens up novel perspectives on works crucial for understanding the Renaissance period, highlighting the necessity of further research in order to comprehend properly this highly complex aspect of Shakespeare's works. The deep ambiguity inherent in Prince Hal's repudiation of Falstaff and in Prospero's controversial and somehow inconsistent final acknowledgment of his "dark side" - "This thing of darkness I | acknowledge mine" (The Tempest 5.1.278-279); the failure of the Stoic and Puritan ideal embodied in Brutus' political mistakes and the tragic outcome of Hamlet's fanatical and paralyzing refusal of his material self ${ }^{16}$ - these are only some of the issues that would benefit from being studied in the light of Shakespeare's reflection on the interaction of specific political, anthropological and philosophical discourses. By fostering a rediscovery of the most compelling and current implications of Shakespeare's work, this approach will help reveal the deep

\footnotetext{
${ }^{16}$ I have addressed some of these issues in The Dark Lady. La rivoluzione shakespeariana nei Sonetti alla Dama Bruna (Caporicci 2013), where I also propose a reading of Shakespeare's Sonnets aimed at re-evaluating the Dark Lady section as a deep meditation on human nature and an example of Shakespeare's mise en question of the neo-Platonic and Christian bases of Petrarchan poetry.
} 


\section{Caporicci}

modernity of his reasoning, proving once again the relevance of a contemporary return to it.

\section{References}

Bakhtin, Mikhail 1993 (1965). Rabelais and His World. Trans. Hélène Iswolsky. Bloomington: Indiana University Press.

Barker, Francis 1984. The Tremulous Private Body: Essays on Subjection. London: Methuen.

Betussi, Giuseppe 1968 (1544). Il Raverta. Ed. Giuseppe Zonta. Trattati d'amore del Cinquecento. Bari: Laterza.

Caporicci, Camilla 2013. The Dark Lady. La rivoluzione shakespeariana nei Sonetti alla Dama Bruna. Passignano s.T.: Aguaplano.

Del Sapio Garbero, Maria 2003. "Plica Ex Plica: Ermione e Perdita." Eds. Viola Papetti and Nancy Isenberg. Le Forme del Teatro. La Posa Eroica di Ofelia. Roma: Edizioni di Storia e Letteratura: 25-53.

DiGangi, Mario 1993. "Pleasure and Danger: Measuring Female Sexuality in Measure for Measure." ELH 6o/3: 589-609.

Elam, Keir 1996. "In What Chapter His Bosom?: Reading Shakespeare's Bodies." Alternative Shakespeares, Vol 2. Ed. Terrence Hawkes. London: Routledge: 140-63.

Enterline, Lynn 2000. "'You speak a language that I understand not': the rhetoric of animation in The Winter's Tale." The Rhetoric of the Body from Ovid to Shakespeare. Cambridge: Cambridge University Press: 198-226.

Esposito, Roberto 2010. Pensiero vivente. Torino: Einaudi.

Ficino, Marsilio 1962 (1576). Theologiae Platonicae, de immortalitate animorum. In Opera Omnia. Torino: Bottega d'Erasmo.

Fox, Alastair 1997. The English Renaissance. Identity and Representation in Elizabethan England. Oxford: Blackwell.

Gish, Dustin A. and Bernard J. Dobski 2013. "Shakespeare and the Body Politic." Eds. Dustin A. Gish and Bernard J. Dobski. Shakespeare and the Body Politic. Plymouth: Lexington Books: 1-27.

Hadfield, Andrew 2004. Shakespeare and Renaissance Politics. The Arden Shakespeare. London: Thomson Learning.

Hamilton, Donna B. 1992. Shakespeare and the politics of Protestant England. Lexington: The University Press of Kentucky.

Hillman, David 2007. Shakespeare's Entrails: Belief, Scepticism and the Interior of the Body. Houndmills and New York: Palgrave Macmillan. 
1997. "Visceral Knowledge." Eds. David Hillman and Carla Mazzio. The Body in Parts. Fantasies of Corporeality in Early Modern Europe. New York and London: Routledge: 81-105.

Holland, Norman N. 1959. "Measure for Measure: The Duke and the Prince." Comparative Literature 11/1: 16-20.

Jardine, Lisa 1989. Still Harping on Daughters: Women and Drama in the Age of Shakespeare. New York: Columbia University Press.

Johnson, Nora 1998. "Ganymedes and Kings: Staging Male Homosexual Desire in The Winter's Tale." Shakespeare's Studies 26: 187-217.

Kantorowicz, Ernst 1957. The King's Two Bodies: A Study in Mediaeval Political Theology. Princeton: Princeton University Press.

Laqueur, Thomas 1986. "Orgasm, Generation, and the Politics of Reproductive Biology." Representations 14: 1-16.

1990. Making Sex: Body and Gender from Greeks to Freud. Cambridge, MA: Harvard University Press.

López-Peláez Casellas, Jesús 2004. "The Neo-Stoic Revival in English Literature of the Sixteenth and Seventeenth Centuries: An Approach." SEDERI Yearbook 14: 93-115.

Luther, Martin 1976 (1515-1516). Commentary on Romans. Trans. J. Theodore Mueller. Grand Rapids: Kregel Publications.

Machiavelli, Niccolò 1976 (1532). Il Principe. Ed. Delio Cantimori. Il Principe e le opere politiche. Milano: Garzanti.

McLaren, Angus 1984. Reproductive Rituals: The Perception of Fertility in England from the Sixteenth Century to the Nineteenth Century. London: Methuen.

Ovid 1995 (2-8 AD). Metamorfosi. Eds. Mario Ramous and Luisa Biondetti. Milano: Garzanti.

Owens, Margaret E. 2005. Stages of Dismemberment: The Fragmented Body in Late Medieval and Early Modern Drama. Newark: University of Delaware Press.

Paster, Gail Kern 1993. The Body Embarrassed. Drama and the Disciplines of Shame in Early Modern England. Ithaca and London: Cornell University Press.

Pico della Mirandola, Giovanni 2004 (1486). Oratio De Hominis Dignitate. Ed. Eugenio Garin. Torino: Nino Aragno.

Rutter, Carol Chillington 2001. Enter the Body: Women and Representation on Shakespeare's Stage. London and New York: Routledge.

Sanders, Eve Rachelle 2006. "The Body of the Actor in Coriolanus." Shakespeare Quarterly 57/4: 387-412. 


\section{Caporicci}

Sawday, Jonathan 1995. The Body Emblazoned. Dissection and the Human Body in Renaissance Culture. London and New York: Routledge.

Schneider, Ben Ross 1993: "Granville's Jezw of Venice (1701): A Close Reading of Shakespeare's Merchant." Restoration. Studies in English Literary Culture, 1660-1700 17, 2: 111-35.

1995: "'Are We Being Historical Yet?': Colonialist Interpretations of Shakespeare's Tempest." Shakespeare Studies 23: 123-45.

Shakespeare, William 2005 (1623). Measure for Measure. Eds. Stanley Wells, Gary Taylor, John Jowett and William Montgomery. The Oxford Shakespeare. The Complete Works. Oxford: Oxford University Press. 2005 (1623). The Tempest. Eds. Stanley Wells, Gary Taylor, John Jowett and William Montgomery. The Oxford Shakespeare. The Complete Works. Oxford: Oxford University Press.

2005 (1623). The Winter's Tale. Eds. Stanley Wells, Gary Taylor, John Jowett and William Montgomery. The Oxford Shakespeare. The Complete Works. Oxford: Oxford University Press.

Schoenfeldt, Michael C. 1999. Bodies and Selves in Early Modern England: Physiology and Inwardness in Spenser, Shakespeare, Herbert and Milton. Cambridge: Cambridge University Press.

Siemon, James R. 2001. "Between the Lines: Bodies/Languages/Times." Shakespeare Studies 29: 36-43.

Stallybrass, Peter 1986. "Patriarchal Territories: The Body Enclosed". Eds. Margaret W. Ferguson, Maureen Quilligan and Nancy J. Vickers. Rewriting the Renaissance: The Discourse of Sexual Difference in Early Modern Europe. Chicago: University of Chicago Press.

Stier, Richard 2011. The Unrepentant Renaissance. Chicago and London: The University of Chicago Press.

How to cite this article:

Caporicci, Camilla. "The tyranny of immaterialism: Refusing the body in The

Winter's Tale." SEDERI 25 (2015): 31-54.

Author's contact: camilla.caporicci@gmail.com

Postal address: Institut für Italienische Philologie der LMU München Schellingstr - 3, Vordergebäude Raum $302-80799$ München, Germany

Submission: 27/01/2014 Acceptance: 11/11/2014 